\title{
Immunoglobulin $G$ absorption from pooled maternal colostrum, commercial powder and freeze-dried colostrum by newborn calves
}

\author{
Aïssata N'DiaYe Wereme ${ }^{\mathrm{a} *}$, Malgorzata Strabel ${ }^{\mathrm{b}}$, \\ Jean-François GRONGNET ${ }^{\mathrm{c}}$, Michel PIOT $^{\mathrm{d}}$ \\ a INERA, Département Productions Animales 03, BP 7192, Ouagadougou 03, Burkina Faso \\ b Akademia Rolnicza ul. Wotynska 33, 60-637 Poznan, Poland \\ c INRA, Laboratoire du Jeune Ruminant, 65 rue de Saint-Brieuc, 35042 Rennes Cedex, France \\ d INRA, Laboratoire de Technologie Laitière, 65 rue de Saint-Brieuc, 35042 Rennes Cedex, France
}

(Received 21 February 2000; accepted 10 July 2001)

\begin{abstract}
For many reasons, a lot of newborn ruminants have no access to their mother's colostrum and are therefore not protected against neonatal diseases. Many commercial colostra-replacers are now available, but their ability to pass the intestinal wall is not well established. Therefore, two experiments were carried out to test the value of two maternal colostra, freeze-dried immunoglobulins extracted from the colostra of Holstein cows, and a commercial dried colostrum powder, as colostrum substitute. Fifty-seven Holstein calves were fed the same immunoglobulin concentration exactly 1, 7 and $15 \mathrm{~h}$ after birth. They were divided into four groups A, B, C and D with respectively 16, 16, 13 and 12 animals. Total immunoglobulin $\mathrm{G}$ concentrations were the highest at $24 \mathrm{~h}$ in all groups but the freeze-dried colostrum was best absorbed. The IgG of the whole and the freeze-dried colostra were well absorbed by the calves: the second meal increased the IgG of the calves over $10 \mathrm{~g} \cdot \mathrm{L}^{-1}$, usually considered as the minimum level of protection of the newborn. The commercial dried colostrum powder was not well absorbed and showed low immunoglobulin levels at $24 \mathrm{~h}$ postpartum. It was concluded that even when colostra are given in the same concentrations to calves, the absorption of immunoglobulins differ, because of the complexity and the probable sensitivity and alteration of colostrum components during technological treatments.
\end{abstract}

birth / calf / colostrum / absorption / immunoglobulin G

Résumé - Absorption des immunoglobines G chez le veau nouveau-né. Pour diverses raisons, de nombreux ruminants nouveau-nés n'ont pas accès au colostrum de leur mère pour se protéger contre les infections néonatales. Des substituts du colostrum sont actuellement disponibles sur le marché mais leur absorption intestinale par le nouveau-né n'est pas clairement établie. Deux

* Correspondence and reprints

Tel: 226 319229; fax: 226319230 or 226340271 ;

e-mail: panimale@ fasonet.bf or wereme_ai@ hotmail.com 
expérimentations ont été conduites dans le but de tester l'absorption de deux « colostra-maternels », d'un colostrum en poudre commercialisé et d'un extrait lyophilisé à partir du colostrum bovin. Cinquante sept veaux Holstein au total ont été répartis en quatre lots A, B, C et D comprenant respectivement 16, 16, 13 et 12 animaux. Chaque groupe a reçu trois repas des différents régimes exactement 1,7 et $15 \mathrm{~h}$ après la naissance. Les quantités d'immunoglobulines $\mathrm{G}$ distribuées par kg de poids vif étaient identiques pour les quatre régimes. Les immunoglobulines des « colostra-maternels » et celles de l'extrait lyophilisé ont été bien absorbées par le veau : dès la $11^{\mathrm{e}}$ heure, les immunoglobulines $\mathrm{G}$ plasmatiques des veaux dépassaient le taux de $10 \mathrm{~g} \cdot \mathrm{L}^{-1}$, habituellement considéré comme nécessaire pour assurer la protection immunitaire du nouveau-né. Quant aux immunoglobulines $\mathrm{G}$ du colostrum commercial écrémé déshydraté, elles ont été mal absorbées, leur taux n'atteignant les $10 \mathrm{~g} \cdot \mathrm{L}^{-1}$ qu'au bout de $19-24 \mathrm{~h}$ après la naissance.

naissance / veau / colostrum / absorption / immunoglobuline G

\section{INTRODUCTION}

The newborn calf as well as all other ruminants and ungulate animals are born virtually agammaglobulinaemic because of placental impermeability to immunoglobulin (Ig) molecules. Therefore, they are very sensitive to neonatal infections. The sole immediate and efficient immunological protection is by passive immunisation with maternal antibodies $[4,9,22]$. These antibodies are transmitted from the intestinal lumen to the blood of the newborn by quick ingestion [22] within $24 \mathrm{~h}$ postpartum [21, 31] of an abundant quantity of colostrum rich in immunoglobulins $[13,33]$. Failure in the transfer of these immunoglobulins endangers the survival and health of the calf $[10,26,31]$. However, for many reasons, a lot of calves, lambs, kids and foals, have no free access to their mother's colostrum: multiple births, acute mastitis, maladapted maternal behaviour mostly at first parturition, viral arthro-encephalitis in goats, etc. These difficulties may be avoided by giving frozen colostrum, and more recently, colostrum replacers which are essentially produced by the newly established colostrum industry. Nevertheless, it is important to be very cautious regarding these nutritional specialties because of frequently obtained low IgG plasma concentrations [33]. Dried standard colostrum made from quantities collected from farm to farm, is often inefficient in providing sufficient immunoglobulins; the reason for this may be that farmers are tempted to deliver not only first milking colostrum, but also those of second and third milkings. In order to preserve a satisfactory concentration of immunoglobulins, colostrum powder could be reconstituted with a reduced amount of water before feeding the newborn. However, this option is not suitable, since it results in a beverage too viscous for bucket or artificial feeding. Another option would consist in the removal of most of the fat and protein of the colostrum. Extraction of immunoglobulins from colostrum, followed by their concentration may be used but according to Grongnet et al. [20], such extracted immunoglobulins are poorly absorbed by the intestine of the newborn calf. Some food additives which might help reestablish the absorption capacity have been tested by the same authors (Grongnet et al. [19]). These additives have been shown to be ineffective and led to reconsider the problem and to think about a possible influence of technological colostrum treatment on immunoglobulin absorption. Two experiments were undertaken to test immunoglobulin $\mathrm{G}$ transfer levels from bovine maternal colostrum, a commercial dried powder colostrum and a freeze-dried colostrum extracted by a specific method, to the newborn calf.

In the first trial, transfer of immunoglobulins from frozen-defrozen colostrum was 
compared to that of commercial colostrum dried powder.

The second trial compared immunoglobulin transmission from freeze-thawed colostrum to that of immunoglobulins extracted from colostrum that were freezedried and reconstituted in aqueous solution.

\section{ANIMALS, MATERIALS AND METHODS}

\subsection{Animals and diets}

All animals used in the study were Holstein calves born at full term in the closed cowshed of a research station, in front of a technician. No veterinary product was used to facilitate parturitions. Calves were separated from their dams immediately after birth, transported to an experimental shed and housed in individual pens and affected, birth after birth, by systemic circular permutation into batches. Twin trials were conducted.

\subsubsection{Trial 1}

This experiment used thirty-two male and female newborn calves. Sixteen calves were fed freeze-thawed skimmed colostrum at a level of $26.7 \mathrm{~g} \cdot \mathrm{kg}^{-1}$ of body weight (A), and 16 others were fed commercial skimmed colostrum powder at the level of $6.9 \mathrm{~g} \cdot \mathrm{kg}^{-1}$ of body weight (B) (Tab. I).

\subsubsection{Trial 2}

In this experiment, thirteen calves were supplied a frozen-thawed colostrum (C) and twelve others were fed freeze-dried colostrum extracts in aqueous solution (D) at $30 \mathrm{~g} \cdot \mathrm{kg}^{-1}$ and $2.38 \mathrm{~g} \cdot \mathrm{kg}^{-1}$ of body weight respectively (Tab. I).

\subsection{Sampling and analysis}

Blood samples were collected in heparinised vials by puncture of the jugular vein

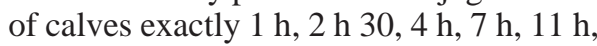
$15 \mathrm{~h}, 19 \mathrm{~h}$, and $24 \mathrm{~h}$ postpartum. Blood was immediately centrifuged and plasma was taken off, frozen and conserved at $-20^{\circ} \mathrm{C}$ for immunoglobulin $\mathrm{G}$ dosage. Rectal temperature was taken after each blood sampling.

IgG concentrations of used colostra were obtained by the radial immunodiffusion technique as described by Mancini et al. [24] and readjusted by Levieux [23]. Rabbit immune serum and bovine purified $\mathrm{IgG}$ were used (Sigma Bovine IgG I-5506), respectively, as the immune serum and standard. Colostra measured IgG concentrations for these substances were as follows:

A $\Rightarrow$ Frozen-thawed colostrum 1: $53 \mathrm{~g} \cdot \mathrm{L}^{-1}$

$\mathrm{B} \Rightarrow$ Commercial dried colostrum powder: $230 \mathrm{mg} \cdot \mathrm{g}^{-1}$

$\mathrm{C} \Rightarrow$ Frozen-thawed colostrum 2: $50 \mathrm{~g} \cdot \mathrm{L}^{-1}$

$\mathrm{D} \Rightarrow$ Freeze-dried colostrum extract: $630 \mathrm{mg} \cdot \mathrm{g}^{-1}$.

Table I. Characteristics of diets used to feed the calves of the different groups.

\begin{tabular}{|c|c|c|c|}
\hline Trial & $\begin{array}{l}\text { Number } \\
\text { of calves }\end{array}$ & Group & Diets and distributed quantities \\
\hline 1 & $\begin{array}{l}16 \\
16\end{array}$ & $\begin{array}{l}\text { A } \\
\text { B }\end{array}$ & $\begin{array}{l}\text { Frozen thawed skimmed colostrum }\left(26.7 \mathrm{~g} \cdot \mathrm{kg}^{-1} \mathrm{BW}\right) \\
\text { Skimmed dried colostrum }\left(6.9 \mathrm{~g} \cdot \mathrm{kg}^{-1} \mathrm{BW} \text { or } 34.5 \mathrm{~g} \cdot \mathrm{kg}^{-1}\right. \\
\text { BW after reconstitution) }\end{array}$ \\
\hline 2 & $\begin{array}{l}13 \\
12\end{array}$ & $\begin{array}{l}\text { C } \\
\text { D }\end{array}$ & $\begin{array}{l}\text { Frozen thawed colostrum }\left(30 \mathrm{~g} \cdot \mathrm{kg}^{-1} \mathrm{BW}\right) \\
\text { Freeze-dried colostrum extract }\left(2.38 \mathrm{~g} \cdot \mathrm{kg}^{-1} \mathrm{BW}\right. \\
\left.\text { or } 27.38 \mathrm{~g} \cdot \mathrm{kg}^{-1} \mathrm{BW} \text { for the reconstituted product }\right)\end{array}$ \\
\hline
\end{tabular}


The four diets were calculated to provide the same dietary quantities of IgG per kg of body weight to calves of the different batches.

In trial 1 , the frozen colostrum was thawed upon each birth in a double boiler at about $50{ }^{\circ} \mathrm{C}$ maximum and distributed to calves after centrifugation, and removal of the lipid.
In experiment 2 , freeze-dried colostrum IgG was obtained from mixing two first milking colostra (frozen at $-20^{\circ} \mathrm{C}$ ) from several Holstein cows in good health and from the same herd, by a specific extraction process described in Figure 1. After thawing for $36 \mathrm{~h}$ in ambient temperature, colostra were mixed in a tank and the $\operatorname{IgG}$ extraction

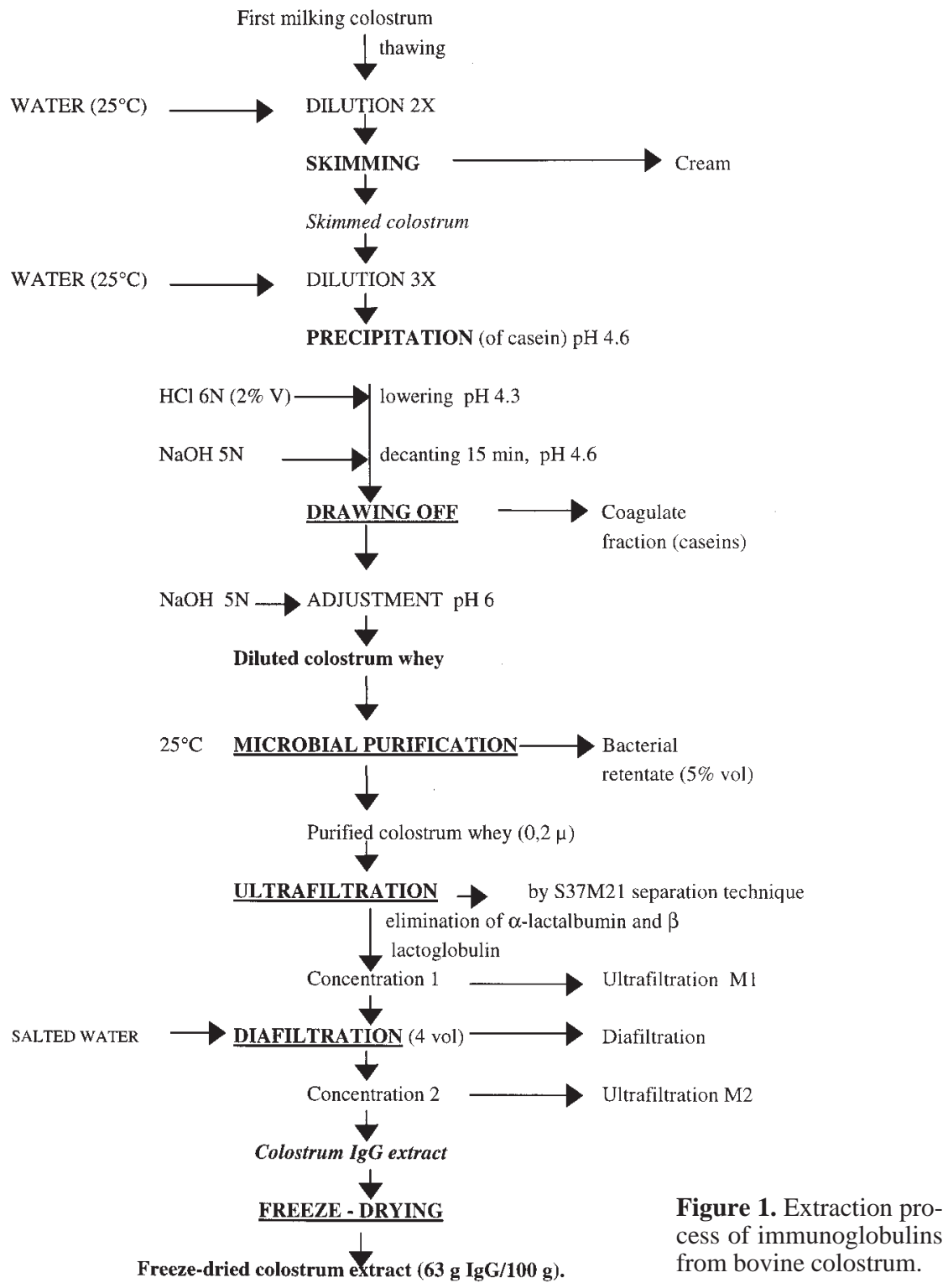


process was applied immediately within the same day.

Three milk meals were fed to calves of different batches with a bucket equipped with a nipple at the bottom at exactly $1 \mathrm{~h}$, $7 \mathrm{~h}$ and $15 \mathrm{~h}$ postpartum. When a calf refused to suck, pressure was practiced on the teat to facilitate intake. In case of persistent refusal, esophageal intubation was applied since the innocuousness of this technique has been previously established [2, $3]$. These events were carefully monitored. Plasma sample IgG concentrations were determined with the same technique used with colostra and which has been cited above.

Data were submitted to the ANOVA factorial test on Statview. To compare groups, the t-test and the Fisher exact probability test were used when necessary.

\section{RESULTS}

\subsection{Weight, appetite, vitality and calves' temperature}

The Calves' weight did not significantly influence their behavior in the different batches. Their appetites for diets A and D were satisfactory for the three meals. On the contrary, more obliged feeding was noted for diet $\mathrm{B}$ and $\mathrm{C}$ at the second and third meal, but the difference between the groups was not significant $(P<0.05)$.

All the calves showed excellent general health during the whole experimental period and even during the consecutive rearing, except for one animal (No. 5086) from batch $\mathrm{D}$ which after being fed three times by intubation died after $24 \mathrm{~h}$ of life.

The evolution of rectal temperature showed a significant difference at $11 \mathrm{~h}$ $(P<0.1)$ between batches $\mathrm{C}$ and group A-B$\mathrm{D}$ and at $19 \mathrm{~h}$ between calves of batches B and group A-C-D (Tab. II). At 11 h postpartum, calves of group $\mathrm{C}$ presented a mean temperature of $37.7 \pm 0.5{ }^{\circ} \mathrm{C}$ whereas the calves in the other groups had a mean temperature which was greater than $38^{\circ} \mathrm{C}$.

\subsection{IgG plasmatic evolution}

The mean plasmatic IgG concentrations recorded for the calves of the three groups are reported in Figure 2. Peak IgG levels were observed at $24 \mathrm{~h}$ for all groups with

Table II. Body weight and rectal temperature of calves supplied frozen-thawed colostrum (1 and 2), commercial dried colostrum powder and freeze-dried colostrum extract, ${ }^{\circ} \mathrm{C}( \pm \mathrm{SD})$.

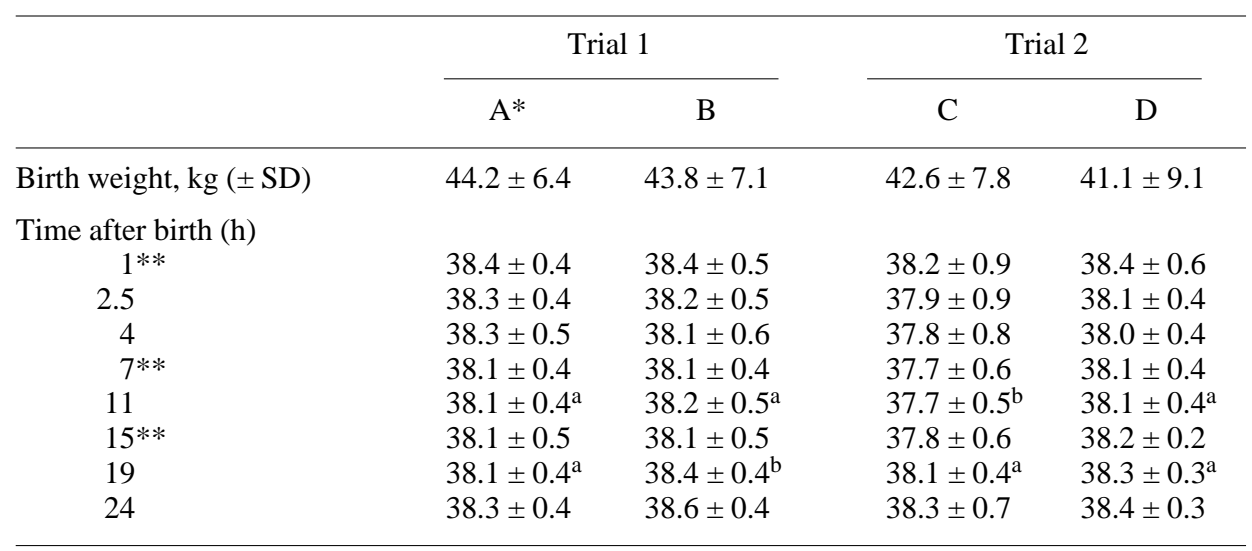

\footnotetext{
* For the number of calves per group, refer to Table I for details.

** Colostrum or colostrum substitute meal.

a.,b On each line, the values with different letters are significantly different $(P<0.1)$.
} 


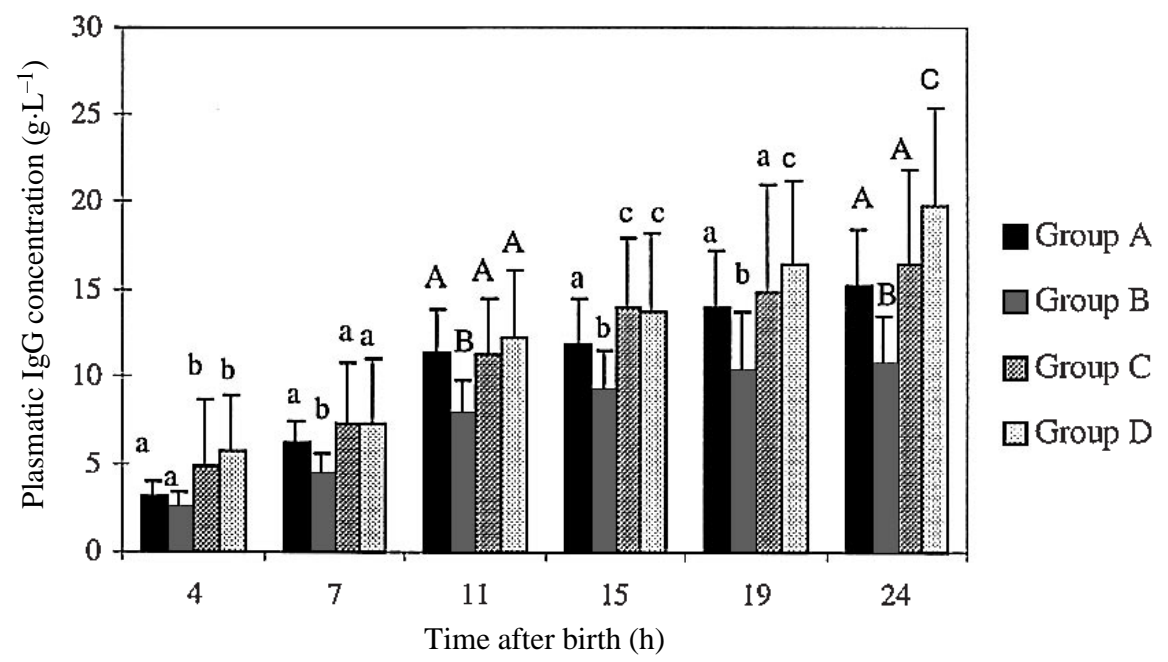

Figure 2. Plasmatic immunoglobulin $\mathrm{G}$ concentrations in calves fed different colostra, $\mathrm{g} \cdot \mathrm{L}^{-1}$ (mean \pm SD). a, b, A, B, C: within each time period, values with different superscripts differ significantly (small letter $P<0.05$; capital letter $P<0.001$ ).

values of $15.2 \pm 3.2 \mathrm{~g} \cdot \mathrm{L}^{-1}, 10.8 \pm 2.7 \mathrm{~g} \cdot \mathrm{L}^{-1}$ $16.4 \pm 5.4 \mathrm{~g} \cdot \mathrm{L}^{-1}$ and $19.7 \pm 5.7 \mathrm{~g} \cdot \mathrm{L}^{-1}$ respectively for groups fed A (frozen-thawed colostrum 1), B (skimmed dried commercial colostrum powder), $\mathrm{C}$ (frozen-thawed colostrum 2) and D (freeze-dried colostrum extract).

\section{DISCUSSION}

\subsection{Calves temperature}

The differences observed in rectal temperatures were significant between groups and can be related to variations between calves with regard to heat production. Nevertheless, the value of $37.7 \pm 0.5^{\circ} \mathrm{C}$ observed in group $\mathrm{C}$ is not comparable to values below $37{ }^{\circ} \mathrm{C}$ for newborn lambs and calf hypothermia reported respectively by Eales and Small [16] and Cartens [11]. Vermorel et al. [32] showed an influence of calf vitality on its rectal temperature when kept in a room at a temperature of $10{ }^{\circ} \mathrm{C}$. On the contrary, calves of group B had a mean temper- ature of $38.4 \pm 0.4{ }^{\circ} \mathrm{C}$ at $19 \mathrm{~h}$, which can be compared to the value of $38.8^{\circ} \mathrm{C}$ observed for calves with good vitality by Vermorel et al. [32]. At $24 \mathrm{~h}$ postpartum, the calves' temperatures in all groups are on a level comparable to those of Vermorel et al. [32] for normal calves. This was an indication that all four diets provided adequate energy levels to the calves.

\subsection{Colostral and plasmatic IgG of calves}

The results obtained with $\mathrm{IgG}$ from freeze-dried colostrum are in contradiction with those of Dos Santos [14] who found that immunoglobulins extracted from colostrum were not as efficiently absorbed by the newborn calf as immunoglobulins in whole colostrum. In the present experiment, the immunoglobulin $\mathrm{G}$ extraction process from colostrum led to a final product which contained $63 \%$ of immunoglobulins. The Ig of this extract were $45 \%$ more absorbed than those of the commercialised skimmed colostrum powder. 
IgG concentrations observed in the study are in agreement with the levels reported by Serieys [27] who gave values of 50 to $80 \mathrm{~g} \cdot \mathrm{L}^{-1}$ for cow colostrum. The value of plasmatic IgG obtained after $24 \mathrm{~h}$ in groups A and $\mathrm{C}$ are distinctly less than the level of $32.8 \pm 1.9 \mathrm{~g} \cdot \mathrm{L}^{-1}$ at $28 \mathrm{~h}$ postpartum related by Grongnet et al. [20] on calves fed 4 first milking colostrum meals, against $25.4 \pm$ $3.5 \mathrm{~g} \cdot \mathrm{L}^{-1}$ for those fed a retentate from colostrum. Plasmatic IgG of $15 \mathrm{~g} \cdot \mathrm{L}^{-1}$ were measured $26 \mathrm{~h}$ after birth in calves fed $44 \mathrm{~g} \cdot \mathrm{L}^{-1}$ maternal colostrum according to Dos Santos [14]. A mean of $18.7 \mathrm{~g} \cdot \mathrm{L}^{-1}$ was obtained by Abel Francisco and Quigley [1] for Holstein calves fed maternal colostrum $24 \mathrm{~h}$ postpartum. Nevertheless, IgG concentrations obtained with groups B and $\mathrm{D}$ (colostrum replacers), respectively $10.8 \pm 2.7 \mathrm{~g} \cdot \mathrm{L}^{-1}$ and $19.7 \pm 5.7 \mathrm{~g} \cdot \mathrm{L}^{-1} 24 \mathrm{~h}$ postpartum, were higher than those reported by Grongnet et al. [20] who indicated values of $6.6 \pm 0.5 \mathrm{~g} \cdot \mathrm{L}^{-1}$ and $8.6 \pm 1.3 \mathrm{~g} \cdot \mathrm{L}^{-1} 28 \mathrm{~h}$ postpartum on calves fed immunoglobulin solutions at a concentration of $83.6 \mathrm{~g} \cdot \mathrm{L}^{-1}$. The IgG levels hardly reached $8 \mathrm{~g} \cdot \mathrm{L}^{-1} 26 \mathrm{~h}$ postpartum for Dos Santos [14] who used additives and a colostrum extract in calves. The literature mentions the influence of many factors in the transfer of colostral Ig in calves: the quantity of ingested Ig, the time lapse before colostrum intake after birth, the feeding method, and genetic, physiological and environmental factors [25, 28]. In the present work, the amounts of Ig distributed to all groups were in equilibrium; measured plasmatic immunoglobulin $\mathrm{G}$ concentrations were satisfactory as early as $11 \mathrm{~h}$ postpartum for calves of batches A, C and D; these levels are in agreement with those of the literature [17, 18, 29, 30]. However, group B which was fed a commercial colostrum powder showed IgG concentrations which were respectively $31 \%$ and $45 \%$ lower than respectively the means of groups $\mathrm{A}$ and $\mathrm{C}$ on the one hand, and $\mathrm{D}$ on the other hand. In fact, $11 \mathrm{~h}$ postpartum, plasmatic IgG of calves in groups A, C and $D$ passed the value of $10 \mathrm{~g} \cdot \mathrm{L}^{-1}$, which is considered to be the minimum level required to ensure the survival of newborn calves [7, 8,18 ] and goat kids [12]. Nevertheless, we noticed that group B at 19-24 h, showed an IgG level always closer to the minimum necessary to ensure immunity protection of the newborn. This agrees with the results from Babiker et al. [5] who obtained better natural colostrum Ig absorption compared to artificial calf feeding.

The lower IgG level measured with the commercial colostrum powder had to be attributed in totality to its nature. Because of its industrial origin, and of the fragility of the immunoglobulins, it is possible that the technological treatment affected some inherent properties of the colostrum and thus limited $\mathrm{IgG}$ absorption. This fact is justified by the same quantities of $\mathrm{IgG}$ fed to whole groups. Balfour and Comline [6] found among others, the effect of a low molecular weight of a protein extracted from colostrum, and which restores immunoglobulin absorption in saline solution. Grongnet et al. [20] obtained an improvement in immunoglobulin absorption by adding milk powder to an immunoglobulin extract from colostrum.

Mean plasmatic IgG levels of calves fed frozen-thawed colostrum compared to those of calves supplied with freeze-dried colostrum extract did not show any significant difference: the freeze-dried colostrum extract was as well absorbed as the natural colostrum. In fact, with an equal IgG level in the diets, these two products showed approximately the same absorption capacity; moreover, a better absorption was noted with the IgG extract $(P<0.05) 24 \mathrm{~h}$ postpartum $(19.7 \pm$ $5.7 \mathrm{~g} \cdot \mathrm{L}^{-1}$ vs. $16.4 \pm 5.4 \mathrm{~g} \cdot \mathrm{L}^{-1}$, Fig. 2$)$. Extracted immunoglobulins from bovine colostrum administered in an aqueous solution have been transferred successfully in newborn lambs [15]. However, calves fed the two colostra (1 and 2) had similar IgG levels until $24 \mathrm{~h}$ postpartum. The process of $\mathrm{IgG}$ extraction from colostrum lead to a product which showed better intestinal absorption of IgG than commercial colostrum powder. A market is perhaps open 
to the industrial production of colostrum derivatives that are really efficient. In view of the many contradictions of literature data on this subject, inter-species differences in the intestinal immunoglobulin transfer from freeze-dried colostrum extract are to be taken into consideration, even if no final explanation can be put forward at this time.

To conclude, it must be recalled that, on a nutritional standpoint, colostrum is a rich product with an exceptional complexity [22]. In fact, colostrum contains elements which are not yet well described but which appear to allow Ig absorption through the intestinal walls and their transport through the blood [14]. Among the factors influencing this absorption by the newborn ruminant intestine, those arising from technological treatments are important, especially with the recent arrival of several commercial products called colostrum-replacers for oral feeding. Particular care must be observed in the industrial elaboration of substitutes of maternal colostrum. The efficiency of the administration of these specialties is obviously determined by an extraction process preserving the immunoglobulins. The absorption of the immunoglobulins depends on a panel of other factors which, when well managed by the breeder, lead to a considerable reduction of neonatal mortality. It is noted that the Ig extraction method used here would be too expensive for industrial production, with prices which would not be reasonable for farmers. It therefore seems necessary to take this aspect into consideration and systematically verify the absorption of different Ig preparations on all target species before any diffusion of the product.

\section{ACKNOWLEDGMENTS}

The authors gratefully thank the research stations of Mejusseaume and Champeaux (INRARennes and Le Rheu) for calve management. They also thank Jacques Lareynie, Jean-Noël Nouchet and Henri Flageul for their contribution to immunoglobulin extraction and for blood sampling.

\section{REFERENCES}

[1] Abel Francisco S.F., Quigley J.D., Serum immunoglobulin concentrations after feeding maternal colostrum or maternal colostrum plus colostral supplement to dairy calves, Am. J. Vet. Res. 54 (1993) 1051-1054.

[2] Adams G.D., Bush L.J., Horner J.L., Staley T.E., Two methods for administering colostrum to newborn calves, J. Dairy Sci. 68 (1985) 773-775.

[3] Al Jawad A.B., Lees J.L., Effects of ewe's colostrum and various substitutes on the serum immunoglobulin concentration, gut closure process and growth rate of lambs, Anim. Prod. 40 (1985) 123-127.

[4] Ashaffenburg R., The nutritive value of colostrum for the calf. 3 . Changes in the serum protein of the newborn calf following the ingestion of small quantities of non fatty fraction. Brit. J. Nutr. 3 (1949) 200.

[5] Babiker B.A., Ahmed F.A., Elhag H.M.A., The effect of natural and artificial colostrum feeding systems on immune globulin concentration in the blood of Crossbred (Kenana $\times$ Friesian) calves, Acta Vet. (Beograd) 38 (1988) 189-194.

[6] Balfour W.E., Comline R.S., Acceleration of the absorption of the unchanged globulin in the newborn calf by factors in the colostrum, J. Physiol. (London) 160 (1962) 234-257.

[7] Besser T.E., Gay C.C., The importance of colostrum to the health of the neonatal calf, Veterinary Clinics of North America: Food Animal Practice 10 (1994) 107-117.

[8] Besser T.E., Gay C.C., Pritchett L., Comparison of three methods of feeding colostrum to dairy calves, JAVMA, Vol. 198, Number 3 , 1991.

[9] Brambell F.W.R., The transmission of passive immunity from mother to young, North Holland research monograph, Frontiers of biology, Vol. 18, 1969.

[10] Braun R.K., Tennant B.C., The relationship of serum gammaglobulin levels of assembled neonatal calves to mortality caused by enterite disease, Agri-practice 4 (1983) 14, 15, 17-24.

[11] Cartens G.E., Cold thermoregulation in the newborn calf, Veterinary Clinics of North America: Food Animal Practice 10 (1994) 69-106.

[12] Constant S.B., Leblanc M.M., Klapstein E.F., Beebe D.E., Leneau H.M., Nunier C.J., Serum immunoglobulin $\mathrm{G}$ concentration in goat kids fed colostrum or colostrum substitute, J. Am. Vet. Med. Assoc. 205 (1994) 1759-1762.

[13] Dardillat J., Trillat G., Larvor P., Colostrum immunoglobulin concentrations in cows: relationship with their calf mortality and with the colostrum quality of their female offspring, Ann. Rech. Vet. 9 (1978) 375-384. 
[14] Dos Santos G.T., Quelques aspects physiologiques et nutritionnels de l'adaptation du ruminant nouveau-né à la naissance : absorption des immunoglobulines extraites du colostrum bovin et perturbations digestives, métaboliques et hormonales provoquées par l'hypoxie, thèse de Doctorat, UER Sciences de la Vie et de l'Environnement, Université de Rennes I, 1987.

[15] Dos Santos G.T., Grongnet J.F., Piot M., Toullec R., Transfert intestinal des immunoglobulines extraites du colostrum bovin, distribuées en solution aqueuse à des agneaux nouveau-nés. Influence de quelques paramètres physico-chimiques et microbiologiques, in: thèse de Grongnet J.F., ENSA de Rennes, publication $n^{\circ} 6,1996$, p. 133.

[16] Eales F.A., Small J., Effects of acute hypoxia on heat production capacity in newborn lambs, Res. Vet. Sci. 39 (1985) 212-215.

[17] Garry F.B., Adams R., Cattel M.B., Dinsmore R.P., Comparison of passive immunoglobulin transfer to dairy calves fed colostrum or commercially available colostral-supplement products, J. Am. Vet. Med. Assoc. 208 (1996) 107-110.

[18] Gay C.C., McGuire T.C., Parish S.M., Seasonal variations in passive transfer of immunoglobulin G1 to newborn calves, J. Am. Vet. Med. Assoc. 183 (1983) 566-568.

[19] Grongnet J.F., Dos Santos G.T., Piot M., Toullec $\mathrm{R}$., Influence of some food additives on $\mathrm{IgC}$ plasma concentrations in newborn calves fed an immunoglobulin solution extracted from colostrum, Le Lait 76 (1996) 303-309.

[20] Grongnet J.F., Grongnet-Pinchon E., Levieux D., Piot M., Lareynie J., Newborn calf intestinal absorption of immunoglobulins extracted from colostrum, Reprod. Nutr. Dev. 26 (1986) 731-743.

[21] Kruse V., A note of the estimation by stimulation technique of the optimal colostrum dose and feeding time at first feeding after the calf's birth, Anim. Prod. 12 (1970) 661-664.

[22] Levieux D., Transmission de l'immunité passive colostrale : le point des connaissances, in: Jarrige R. (Ed.), Physiologie et pathologie périnatales chez les animaux de ferme, INRA Paris, 1984, pp. 345-369.
[23] Levieux D., Dosage des IgG du lait de vache par immunodiffusion radiale semi-automatisée, pour la détection du colostrum, des laits de mammites ou de fin de gestation. I. Mise au point du dosage, Le Lait 71 (1991) 327-338.

[24] Mancini G., Carbonara A.O., Heremans J.H., Immunochemical quantification of antigens by single radial immunodifusion, Immunochemistry 2 (1965) 235-254.

[25] McEwan A.D., Fisher E.W., Selman I.E., Observation on the immune globulin levels of neonatal calves and their relationship to disease, J. Comp. Pathol. 80 (1970) 259-265.

[26] Michanek P., Ventorp M., Weström B., Intestinal transmission of colostral antibodies in newborn dairy calves. Initiation of closure by feeding colostrum, Swedish J. Agric. Res. 19 (1989) 125-127.

[27] Serieys F., Le colostrum de vache, Smith Kline Beecham, Ploufragan, France, 1993.

[28] Shearer J., Mohammed H.O., Brenneman J.S., Tran T.Q., Factors associated with concentrations of immunoglobulins in colostrum at first milking post-calving, Prev. Vet. Med. 14 (1992) 143-154.

[29] Singh A., Ahuja S.P., Individual variation in the composition of colostrum and absorption of colostral antibodies by the precolostral Buffalo calf, J. Dairy Sci. 76 (1993) 1148-1156.

[30] Stott G.H., Marx D.B., Menefee B.E., Nightengale G.T., Colostral immunoglobulin transfer in calves. III. Amount of absorption, J. Dairy Sci. 62 (1979) 1902-1907.

[31] Ventorp M., Michanek P., The importance of udder and teat conformation for teat seeking by the newborn calf, J. Dairy Sci. 75 (1992) 262-268.

[32] Vermorel M., Dardillat C., Vernet J., Saido, Demigné C., Thermorégulation de l'agneau et du veau nouveau-né, in: Jarrige R. (Ed.), Physiologie et pathologie périnatales chez les animaux de ferme, INRA Paris, 1984, pp. 153-176.

[33] Zaremba W., Guterbock W.M., Holmberg C.A., Efficacy of dried colostrum powder in prevention of disease in neonatal Holstein calves, J. Dairy Sci. 76 (1993) 831-836. 
A. N'Diaye Wereme et al. 